\title{
ASIAN CURRENT ACCOUNT BALANCES AND SPILLOVERS FROM A FOREIGN COUNTRY, A REGION AND THE UNITED STATES
}

\author{
Seema Narayan \\ School of Economics, Finance and Marketing, Royal Melbourne Institute of Technology University, \\ Melbourne, Australia. Email: seema.narayan@rmit.edu.au.
}

\begin{abstract}
This paper provides an overall picture on the influence of domestic and foreign shocks on the current account of selected Asian countries over the period 1978 to 2012. The present value model of the current account theory states that forward looking and consumption smoothing behaviour of economic agents can promote sustainable current account balances, as long as these are maintained by transitory unanticipated shocks to the current account. The unexpected transitory domestic and foreign shocks are sourced, respectively, from the domestic and foreign current account. Foreign shocks are developed from an Asian country, a region, and the US. Our empirical analysis of the impact of foreign and domestic current account shocks shows that unexpected domestic shocks, rather than unexpected foreign shocks, matter for the current accounts of Asian countries.
\end{abstract}

Keywords: Current account imbalance; Domestic shock; Spillovers; Unexpected shocks. JEL Classifications: F15; F32; F41.

Article history:

Received : November 13, 2019

Revised : : December 4, 2019

Accepted : December 15, 2019

Available online : February 14, 2020

https://doi.org/10.21098/bemp.v23i1.1207 


\section{INTRODUCTION}

Which shocks - domestic or foreign- are important in the determination of the current accounts of Asian countries? This line of inquiry is consistent with the much of the literature on the current account. This study aligns itself with the present value model of the current account, which notes that a forward looking agent would resort to foreign borrowing to finance any unexpected increase in net output (or income less investment and government spending) so that his/her consumption pattern is unaffected (see, Obstfeld and Rogoff, 1996; Sheffrin and Woo, 1990; Otto, 1992; Ghosh, 1995; Bergin and Sheffrin, 2000; Iscan, 2002). The present value model of the current account implies the importance of temporary unexpected shocks in the determination of the current account (also, see Equation 1).

The current account literature notes that foreign factors can also influence the current account. Studies, such as, Edwards (1989) used the intertemporal approach to the current account to connect the current account to foreign prices through the real exchange rates. Other models, namely, the Mundell and Fleming model or the open economy portfolio-balance approach used by Greenwood (1983), have also been used to study the influence of exchange rate on the current account. While Edwards and the Mundell and Fleming models argue that the effect of exchange rate on the current is positive and negative, respectively, Greenwood (1983) argues that this is ambiguous. ${ }^{1}$ Several other studies include the terms of trade or commodity prices to capture the effects of prices of traded goods (see Cashin and McDermott, 2002). Apart from foreign prices, several empirical studies have also showed the influence of foreign income influencing the current account (see, Kaufman et al., 2002; and Dibooglu, 1997). Empirical studies have accordingly tested the impact of commodity prices, domestic and foreign output, real interest rate, and real exchange rate as some of the key determinants of the $C A$ (see, inter alia, Cashin and McDermott, 2002; Ahmed and Park, 1994; Kent and Cashin, 2003; Hossain, 1999; Chinn and Prasad, 2003; and Kaufmann, et al., 2002).

In terms of the type of shocks that influences the current account, one other important result of the two-country intertemporal model is that worldwide or global shocks do not impact the current account if countries are symmetric. This outcome has found empirical support in several studies (see, Glick and Rogoff 1995; Gregory and Head, 1999; Iscan, 2000; Nason and Rogers, 2002; Narayan, 2014). Glick and Rogoff (1995) show that worldwide and country-specific shocks (common productivity shocks between G7 countries) lead to fluctuations in investment and only country-specific investment is related to the deterioration of the current account. Glick and Rogoff (1995) showed that investment in developed nations is largely driven by global productivity shocks. However, because the current account is unaffected by global shocks, this leads to a weak relationship between investment and the current account. Narayan (2014) examined whether the Glick and Rogoff result - that global shocks do not matter for the determination of the current account - is also applicable to common current account shocks in the case of OECD countries. The study implies that common shocks do not matter for the determination of the current account (see, Narayan, 2014).

Given that there are several domestic and foreign factors influencing the current account, the aim of this study is to shed some light on the overall picture

\footnotetext{
1 See Narayan (2009).
} 
on the relative importance of domestic and foreign shocks in the determination of the current account. We run multivariate regression model of the current account against anticipated/unanticipated transitory foreign and domestic shocks. Foreign shocks are defined as foreign country, the US, or regional spillovers. Foreign country spillovers are current account innovations of a foreign country; regional spillovers are the gross national income weighted unexpected components of the current accounts of 10 of the 11 Asian countries examined; and the US spillovers are innovations from the US current account.

The paper differs from the current literature in three important ways. First, unlike the literature which is still heavily focused on the OECD countries, this paper examines the importance of domestic or foreign shocks for 10 emerging Asian economies, including, Japan. The dynamic economies of Asia are heavily engaged in international trade and foreign investment, which have contributed to the economic and financial integration of these countries, although not fully. ${ }^{2}$ Nonetheless, they are exposed to similar shocks through economic and financial integration. ${ }^{3}$ Moreover, they are active participants in global imbalances (see further discussion in detail in Section 2).

Second, this paper, for the first time, tests the importance of foreign and domestic shocks on the current account. The standard present value model of the current account shows the current account as a function of the conditional mean of future stochastic variables, $Y, I$, and $G$ (Equation 1). Indeed, the implications of both domestic and foreign shocks on variables, $Y, I$, and $G$, cannot be discounted for the Asian nations. These nations are diverse enough to be affected by countryspecific factors. At the same time, these are integrated into the world economy, both economically and financially to be influential foreign factors such as those relating to trade and foreign capital. As a result, this study re-organises the current account function in terms of unexpected foreign and domestic shocks.

Third, since the paper covers aggregate domestic and foreign shocks, it is difficult to source these shocks specifically from a nation's $Y, I$, or $G$, due to unavailability of such data. As a result, foreign and domestic shocks are sourced from the current accounts of a foreign and domestic country (see Equation 5).

To foreshadow our key results, the study finds that all three unanticipated foreign shocks - from a foreign country, region, or from the US - fail to have any significant influence on the current account imbalances of Asian countries. In many pairwise cases, we find that expected foreign shocks also do not matter for the determination of the current account. Unanticipated domestic shocks, on the other hand, matter for the determination of the current account.

The remainder of the paper is organised as follows. The next section discusses the current account imbalances of selected emerging Asian countries, the US, and Japan. Section III explains the data while section IV presents the empirical analysis on the influence of domestic and foreign shocks on the current account. Section V concludes the study.

\footnotetext{
2 We discuss the implications of these engagements on the current account in Section 2.

3 For trade, see for example, Narayan (2019); Narayan and Nguyen (2015; 2019); and Narayan and Bui (2019). For studies on financial integration, see Wälti (2011); Longin and Solnik (1995); Narayan et al (2014); Narayan and Rehman, (2017; 2018; 2019).
} 


\section{CURRENT ACCOUNT IMBALANCES}

In this section, we examine the current accounts of Asian countries and the US over the period 2005-2012. Their current account balance, expressed in US\$ and as a percentage of gross domestic product (GDP) over the period 2005 to 2012, are presented in Tables 1 and 2. China, Japan, Singapore, Malaysia, Korea, and the Philippines (in descending order in US\$ terms) showed persistently large current account surpluses throughout the eight years. The large current account surpluses contributed to a strong foreign reserve position for those countries.

The same is true for Indonesia and Thailand, although they also experienced at least one deficit during this period. Expressed as a percentage of their GDP, the current account of Singapore topped the list with current account surplus averaging nearly $21 \%$ over eight years. This was followed by Malaysia (13.9\%), China (5.8\%), Japan (3.1\%), the Philippines (3.2\%), Thailand (2.1\%), Korea (1.8\%) and Indonesia (0.7\%). On the other hand, the US, India, Pakistan and Sri Lanka registered deficits throughout the eight years. Average current account deficit as a percentage of GDP for these four countries was $4.0 \%, 2.4 \%, 4.0 \%$ and $5.2 \%$, respectively.

To identify the key domestic activities behind the persistently large current account balance, we use the national income accounting identity consistent with the income expenditure approach (see Equation 1). In Figure 1, we present the current accounts as well as expenditure components (household consumption, government spending and investment), all as a percentage of GDP and averaged over the period 2005 to 2012. Complementing this is Figure 2, which shows gross savings and investment, both expressed as a percentage of GDP.

Figure 1.

\section{Current Account, Consumption, Government Spending, and Investment (in \% of GDP)}

Current account balance, consumption, investment, government spending, and investment, all as a percentage of GDP, are averages over the period 2005-2012.

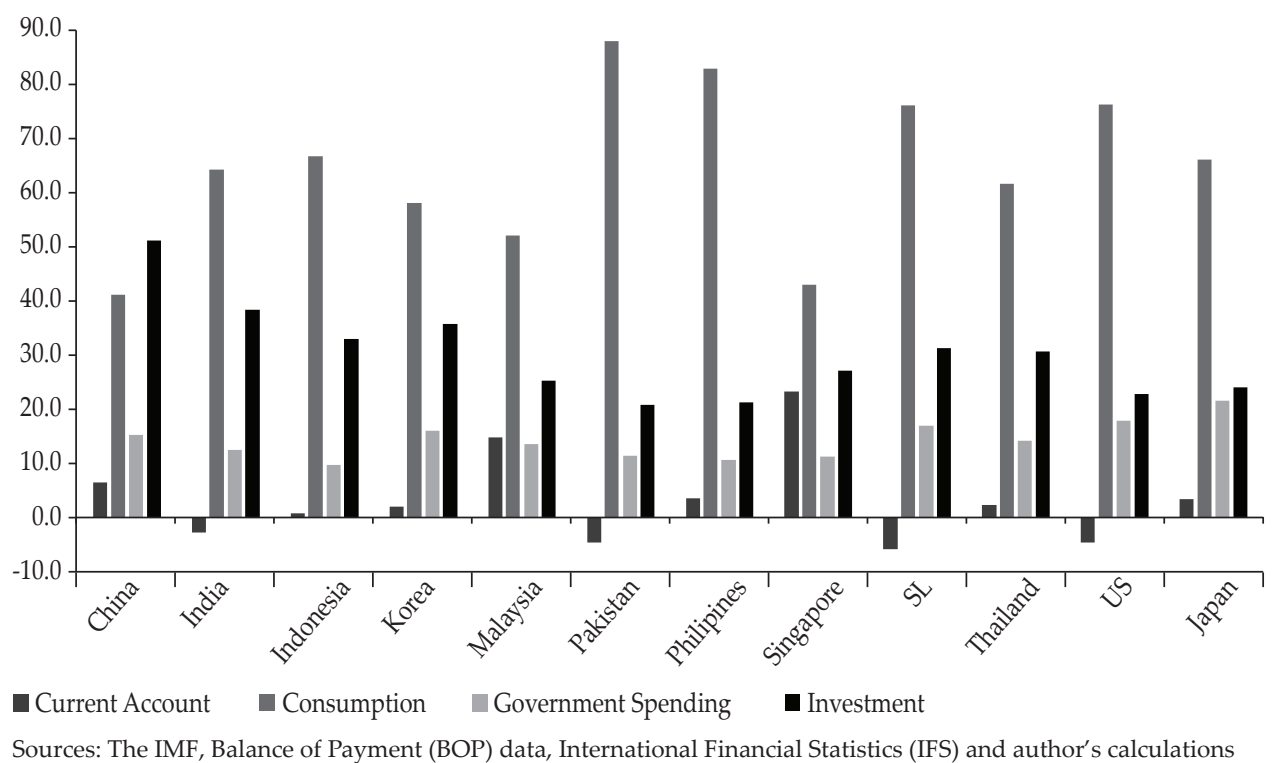




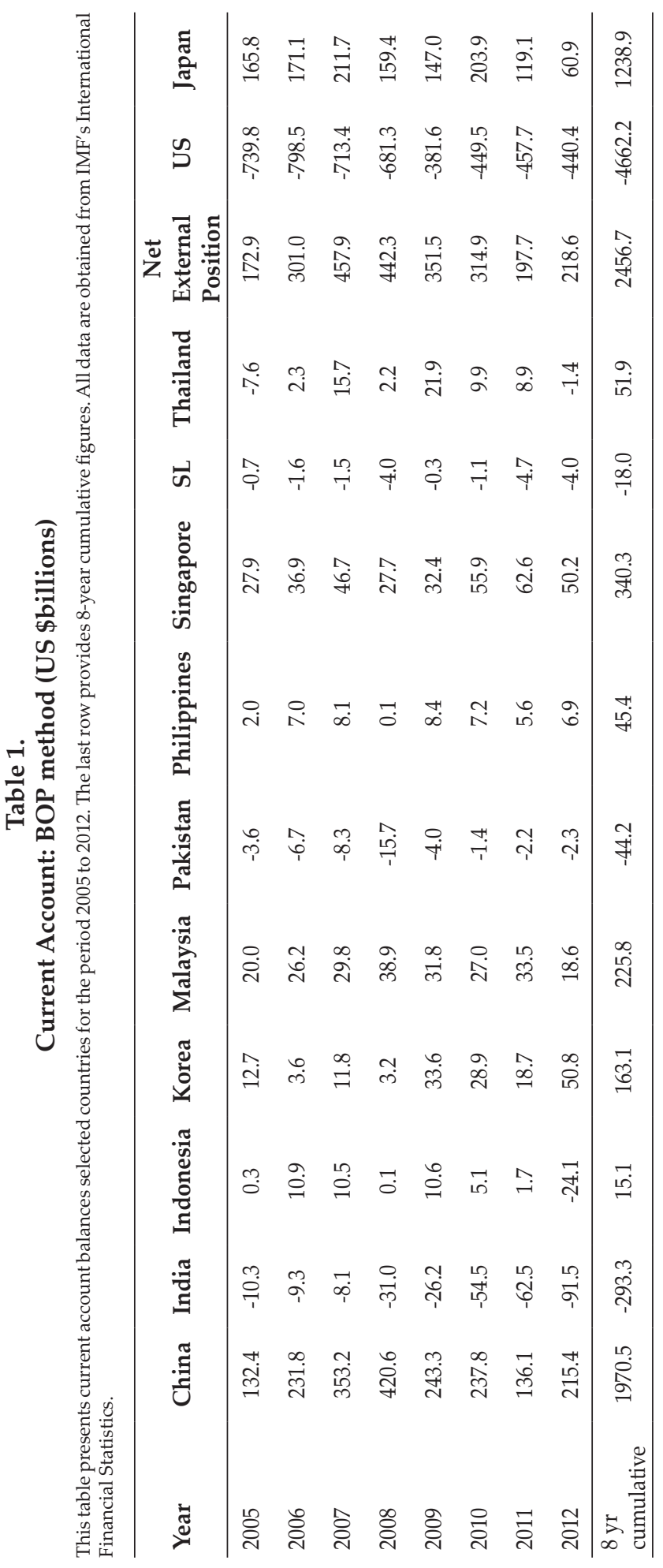




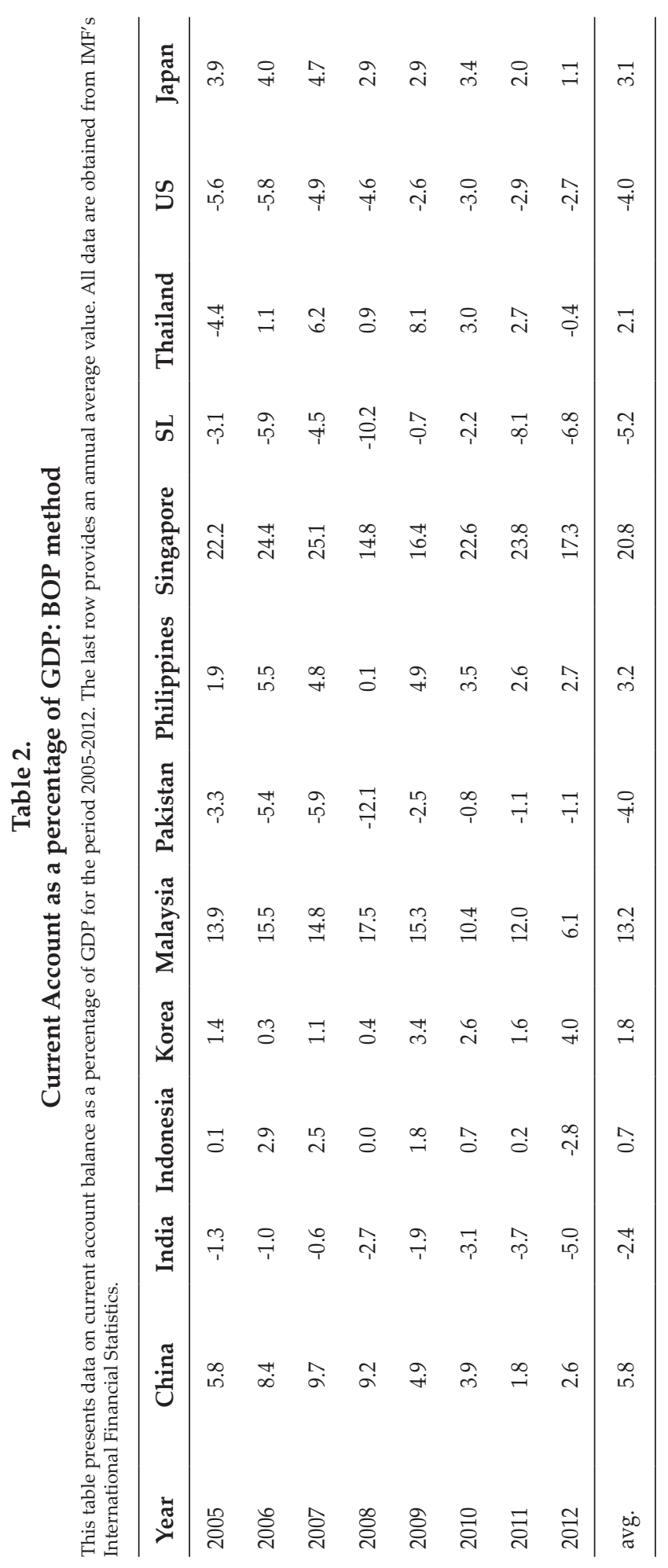


From Figure 1, notice that consumption as a percentage of GDP is rather low in some countries, namely, China, Singapore, Malaysia and Korea, that experienced persistently high current account surpluses. As a consequence, savings in these nations were also rather strong (see Figure 2) and higher than domestic investment. This savings-investment gap has been described in the literature as both an investment drought and a savings glut (see, Gruber and Kamin, 2007). In the current account literature, both have been identified as reasons for the large current account surpluses in Asia. It is worth noting that, on average, it seems that Singapore, Malaysia and the Philippines were contributing more to the savings glut than China (or Indonesia and Thailand). Of course, these current account surpluses were also a result of strong growth in exports, which is the direct result of the outward looking government policy adopted in the Asian nations. An undervalued Chinese exchange rate has also been perceived as a reason for the strong current account position in Asia (see, Corden, 2009).

Ogawa and Iwatsubo (2009) showed that real exchange rates of East Asian countries do affect their current accounts but economic growth rather than the real exchange rates is the key determinant of the Chinese current account balance. Some researchers have also argued that the current account surplus is a sign of weak or underdeveloped financial institutions, unable to convert saving into capital (see, Hubbard, 2006). As a result, capital from developing nations flows to nations with more developed and safer financial markets (Mendoza et al., 2007). However, Gruber and Kamin (2009) and Chinn and Ito (2007a, b) found that in Asian countries, greater financial development is associated with higher current account balances.

\section{Figure 2. \\ Saving and Investment (in \% of GDP)}

This figure depicts savings and Investment as a percentage of GDP averaged over the period 2005-2012.

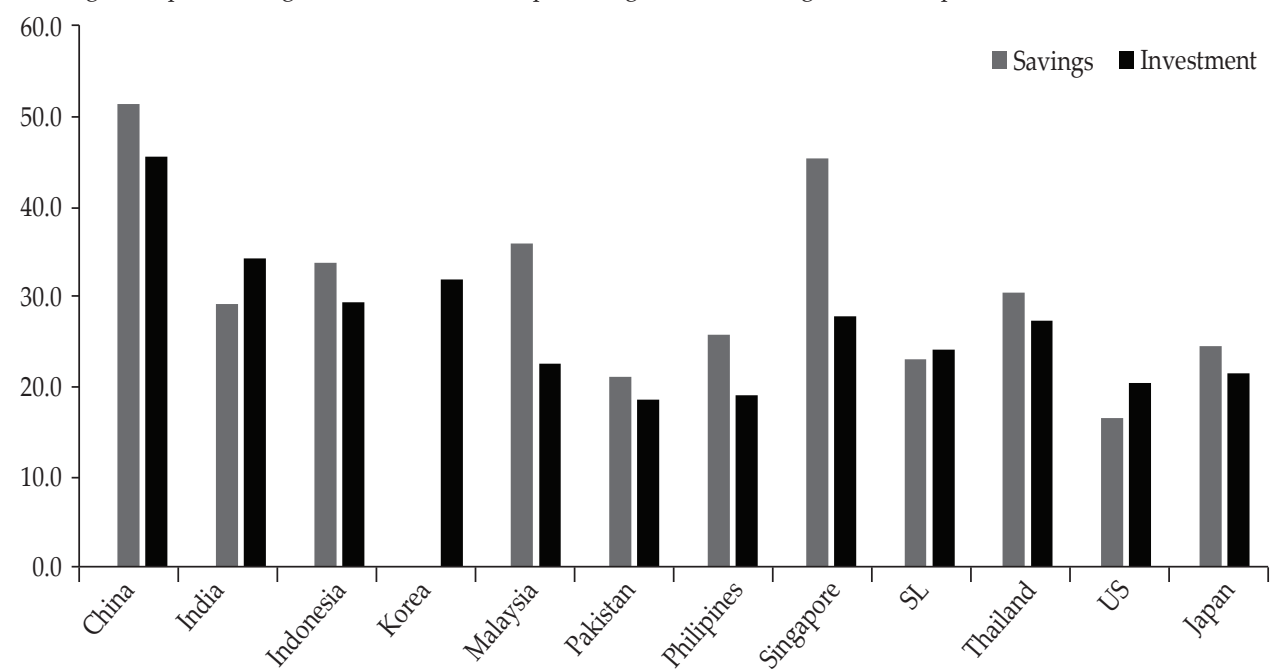

Source: The IMF, Balance of Payment (BOP) data, International Financial Statistics (IFS); The World Bank website: http://data.worldbank.org/indicator/NY.GNS.ICTR.ZS/countries?display=default 
We can also see that China is the only country with a current account surplus that, on average, was propelled largely by investment/saving. China's household consumption has averaged $37 \%$ of its GDP, while investment has been around $46 \%$ (see Figure 2). Yang (2012) noted similar trends, and attributes these to domestic policies, institutions and structural distortions embedded in the Chinese economy. Yang argues that China's accession to the World Trade Organization, its export-oriented policies, and its reforms in the labour market have vastly increased wealth. However, because social welfare and other areas of the Chinese economy have been neglected, this has increased savings and kept household consumption and imports low. Hoffman (2013) found evidence that, for China, expected declines in net output (GDP less investment and government spending) and expected increases in prices of non-tradeables (such as, housing and medical care) are the main channels of current account adjustment.

In contrast, the US has been characterised as a nation spending beyond its means -its current account is driven by household consumption. The US deficits have indeed fallen from pre-GFC levels but, as many economists have suggested, a reversal of the US current account is likely to be slow and painful if adjustment is to rely on exchange rate changes (see Rogoff, 2007; Engler et al. 2009). Some of the persistently large deficits in Asia (specifically, Pakistan, Sri Lanka and India) have also been driven by household consumption.

The consumption smoothing approach to the current account sees the current account deficit as a sign that a nation is smoothing its income by borrowing externally. Nations in transition are also mostly characterised by current account deficits because of their reliance on foreign capital to finance their domestic investment and growth. Hence, while the modern theory of the current account deficits perceives the consumption smoothing behaviour as inevitable, if current accounts (deficit or surplus) become large, persistent, and are driven by household consumption and government spending (twin deficit), these are at risk of becoming unsustainable.

In fact, Kim et al. (2009) found that the current accounts of five Asian countries (Indonesia, Korea, Malaysia, the Philippines and Thailand) were on sustainable paths and provided evidence in support of the intertemporal approach to the current account for these countries. Further, Hoffman (2013) showed that the present value model - a simple version of the intertemporal model - explained $70 \%$ of the variation in the Chinese current account and suggested that China was also on a sustainable path.

\section{DATA}

The paper relies on the current account imbalance series, which is calculated following the income-expenditure method, as Gross National Income (GNI) less the sum of investment, household consumption and government spending. This definition avoids the problem of encountering a lack of consistent data that comes with using the Balance of Payment (BOP) or net foreign asset definition for the developing countries. The BOP measure also comprises errors and omissions which are arbitrarily allocated. The net foreign assets definition of the current account suffers from the associated difficulties of calculating the net foreign assets 
position (Sheffrin and Woo, 1990). The resulting current account imbalances are further defined as a ratio of GDP, and are hereon referred to as CA.

The macroeconomic times series used for the calculation of the current account are sourced from the International Monetary Fund database, the International Financial statistics. While the highest frequency of the data is often quarterly, consistent quarterly series for most of the selected Asian countries is not available. As a result, we use annual data over the period 1978 to 2012. The period 19782012 captures one of the most turbulent periods for Asian countries, as far as the current account is concerned. The period leading up to early 1990s saw adoption of major economic reforms by the region along the lines of trade and financial liberalization, both of which had significant implications for the current account of the Asian countries. The second half of the 1990s leading up to 2012, saw major financial crises affecting Asia, including, the Asian Financial crisis (1997-1998) and the Global Financial crisis (2007-2009), which influenced the flow of funds and goods and services. Further, a good part of the 2000s saw Asian countries strongly engaging in export-led-growth, which contributed to the persistently large current account surpluses in a number of the Asian countries (Section 2).

\section{A. Preliminary Examination of the Data}

Before commencing the empirical analysis, we undertake a preliminary examination of the data. In Table 3, we provide the common descriptive statistics of the variables over the period 1978 to 2012. Averaged over this period, the current account of Singapore registered the largest surplus, 11.5\% of GDP. Other nations, the Philippines (5.4\%), Malaysia (4.5\%), Japan (2.6\%) and Korea (0.1\%) followed suit. The nations that experienced a deficit on average are Sri Lanka (-21.4\%), India $(-5.3 \%)$, the US $(-2.3 \%)$, Indonesia $(-2.0 \%)$, Thailand $(-1.5 \%)$ and China $(-0.3 \%)$. The Coefficient of Variation (CV) suggests that the current accounts of Korea and China were the most volatile. The others seemed to be rather stable.

The current account as a percentage of GDP of China, Indonesia, Korea, Pakistan and Japan are weakly skewed and display excess kurtosis. The JarqueBera statistics, however, suggest that the normality assumption cannot be rejected.

The time series properties of the current account are tested using the conventional ADF test. Here, the null hypothesis of the presence of a unit root against the alternate of no unit root was tested. The tests were conducted with an intercept, implying that the current account is mean reverting. This is consistent with the modern current account theory which suggests that the current account is influenced only by transitory shocks, is mean reverting in nature (see Equation 1 ). In case the null is rejected or the current account imbalances are found to be $I(0)$ or mean reverting, this would indicate that the current account is on a sustainable path and if the current account is found to be $I(1)$, then the current account balances are unsustainable. ${ }^{4}$ Lag length selection was based on the Schwarz information criterion. Our results show that most countries studied, with the exception of Indonesia, Korea, and Pakistan, faced non-stationary current accounts in level form, or they were I(1). In other words, current accounts of all, except, Indonesia,

\footnotetext{
4 See Narayan (2009).
} 


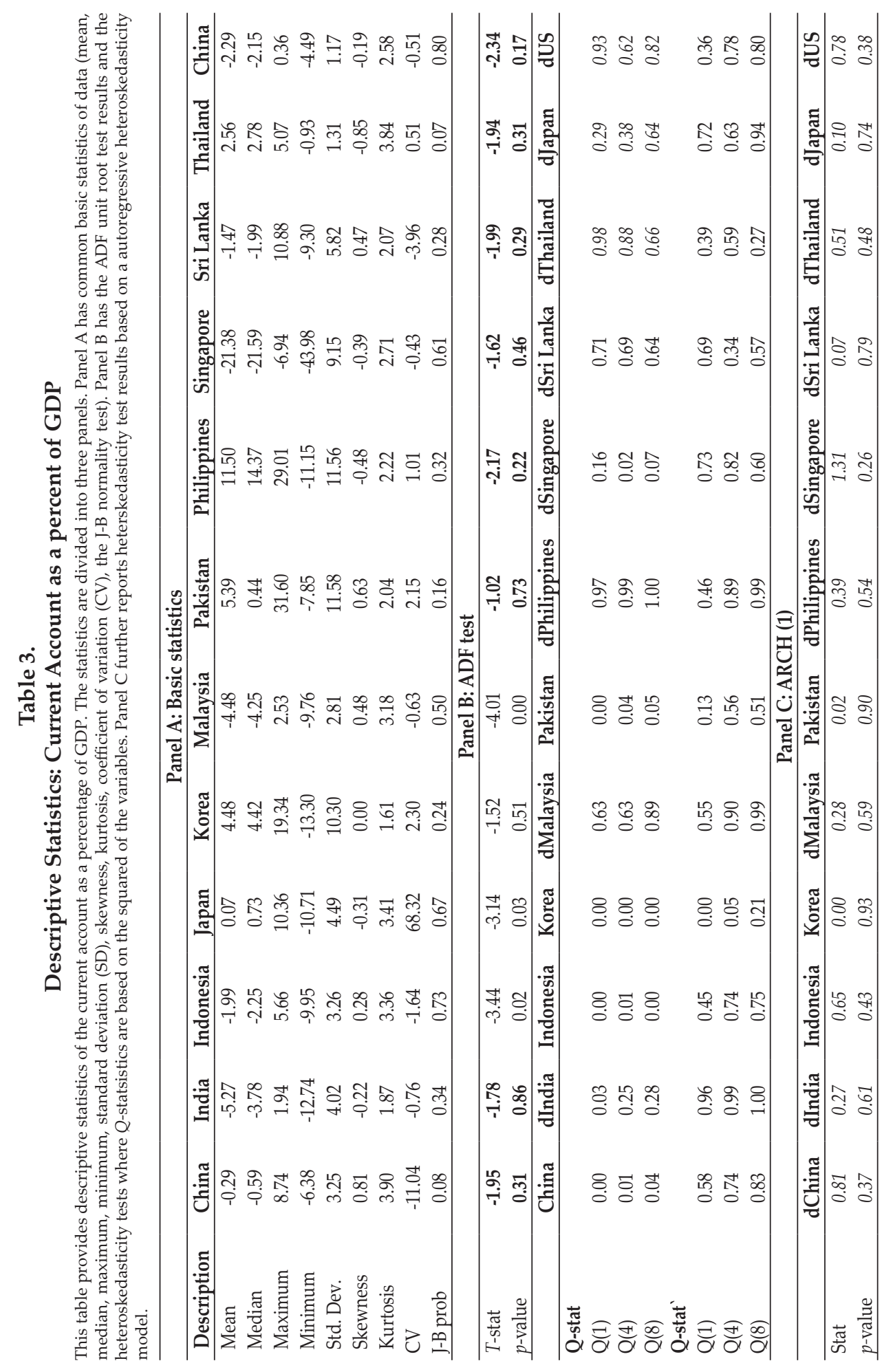


Korea, and Pakistan, were unsustainable over the period 1978-2012. The I(1) variables appear in first difference form in the rest of the paper.

Finally, we conduct a few tests to determine whether these series are affected by serial correlation and heteroskedasticity. The $Q$-statistics for the current account series (all in stationary form) indicate serial correlation in the case of China, Indonesia, Korea, Pakistan and Singapore. The $p$-values on the $Q$-statistics on the squared of the current account suggest no case of heteroskedasticity. Similarly, the ARCH test (conducted with one lag) suggests that current accounts are not affected by heteroskedasticity.

\section{EMPIRICAL ANALYSIS}

\section{A. The Influence of Unexpected Shocks}

Next, to test the importance of domestic and foreign shocks, we examine the direct impact of current account innovations on the current account. We begin our analysis by examining the influence of unexpected shocks on the current account. To show the theoretical motivation, we rely on Obstfeld and Rogoff (1996), which derives a representation of the current account by optimising lifetime utility of an infinitely-lived individual who prefers to keep consumption consistent throughout his/her lifetime. The representative individual lives in a small open economy where the supply of labour is assumed to be inelastic and there is no disutility from working. This economy takes the world interest rate as exogenous and can be likened to a small open economy with no influence on the world interest rate, and the discount factor, $\mathrm{R}_{\mathrm{t}, \mathrm{s}^{\prime}}$ is assumed to be constant. The optimization problem involves maximising lifetime utility, which is defined as the weighted sum of all expected future flows of utilities, subject to an intertemporal budget constraint.

This leads to the development of the fundamental current account model:

$$
C A_{t}=\left(Y_{t}-E \tilde{Y}_{t}\right)-\left(I_{t}-E \widetilde{I}_{t}\right)-\left(G_{t}-E \widetilde{G}_{t}\right)
$$

Here, E\{.\} is the operator for the conditional expectation and $E \widetilde{Y}_{t}, E \widetilde{I_{t}}, E \widetilde{G_{t}}$ are the permanent levels of $Y, I, G$. Equation (1) states that transitory fluctuations in net national output $(H)$ (output $(Y)$ less investment $(I)$ and government spending $(G)$ ) are equal to the current account balances (CA). More importantly, it shows that the individual would resort to foreign borrowing to finance any unexpected increase in investment so that his/her consumption pattern is unaffected.

Next, Campbell's (1987) framework is used to derive a current account equation that can be tested empirically. Given that the interest rate is constant, the expected permanent level (or the conditional mean) of variable $X$ (where $Y, I$ or $G$ ) at date $t$ is defined as:

$$
\sum_{s=t}^{\infty}\left(\frac{1}{1+r}\right)^{s-t} E \tilde{X}_{t}=\sum_{s=t}^{\infty}\left(\frac{1}{1+r}\right)^{s-t} E X_{s}
$$


Rearrange this so that $\tilde{E X}_{t}$ is the subject, we get:

$$
\mathrm{EX} \widetilde{\mathrm{t}}_{\mathrm{t}}=\frac{\mathrm{r}}{1+\mathrm{r}}\left[\sum_{\mathrm{s}=\mathrm{t}}^{\infty}\left(\frac{1}{1+\mathrm{r}}\right)^{\mathrm{s}-\mathrm{t}} \mathrm{EX}_{\mathrm{s}}\right]
$$

Using the definition of net output $(\mathrm{H})$, the above expression of the current account (1) can be rewritten as:

$$
C A_{t}=Z_{t}, \text { where } Z_{t}=H_{t}-E \widetilde{H_{t}}
$$

where, $Z_{t}$ is the temporary unexpected shocks to net output.

Equation (4) carries the implication of the consumption smoothing behaviour of economic agents, that the current account is influenced by transitory unexpected shocks emanating from net output. Since the influence of domestic and foreign shocks on net output or the current account cannot be ruled out, we examine whether unexpected shocks $\left(Z_{t}\right)$ emanating from the domestic economy $\left(Z_{1, t}\right)$; and a foreign country $\left(Z_{2, t}\right)$; the region $\left(Z_{\text {reg,t }}\right)$; or/and the US economy $\left(Z_{u S, t}\right)$ can explain the current account (Equation 5).

In this paper, the unanticipated shocks $(Z)$ are derived as the current account innovations from foreign countries (from all 10 Asian countries); the Asian region (including Japan); and the US. The current account innovations are extracted from an $\operatorname{AR}(p)$ model of the current account (see Section 4.2). According to the standard unit root test, these unexpected shocks are mean reverting; as a result, these shocks are temporary. ${ }^{5}$ In what follows, we use these definitions of unanticipated shocks to examine their influence on the current account.

\section{B. Unexpected Spillovers from a Domestic and a Foreign Country}

We begin the analysis by focusing on unexpected country-specific and foreign shocks in pairwise relations. Consistent with the standard intertemporal predictions, we examine the current account in term of unexpected shocks, but, as noted above, we define these in terms of domestic and foreign shocks. In other words, the unexpected output, investment and government spending shocks are re-organised as domestic and foreign shocks, leading to the following equation:

$$
C A_{i, t}=\beta Z_{1, t}+\beta Z_{1, t-1}+\beta Z_{2, t}+\beta Z_{2, t-1}+\varepsilon_{t}
$$

where, $Z_{1}$ is the domestic current account innovations and $Z_{2}$ is the foreign current account innovations, both derived from estimating the $\operatorname{AR}(p)$ model of the current account. Here an AR (1) structure is imposed on the current accounts of most domestic and foreign countries $i$ and $j$ :

5 These results are available on request. 


$$
\begin{aligned}
& C A_{1, t}=\alpha_{1}+\beta_{11} C A_{1, t-1}+Z_{1, t} \\
& C A_{2, t}=\alpha_{2}+\beta_{12} C A_{2, t-1}+Z_{2, t}
\end{aligned}
$$

$C A_{1}$ and $C A_{2}$ are the current account of the domestic and foreign country, respectively. The residuals show no sign of serial correlation once this structure is used for all cases, except Singapore - for which we find the AR (2) process is statistically better suited. The least squares estimator is used to estimate Equations (6) and (7). Once equations (6) and (7) are estimated, the domestic and foreign current account innovations are, respectively, derived as: $C A_{1, t}-\alpha_{i}-\beta_{11} C A_{1, t-1}=Z_{1, t}$ and $C A_{2, t}-\alpha_{i}-\beta_{12} C A_{2, t-1}=Z_{2, t}$. A pairwise correlations test between the domestic and foreign current account innovations, $Z_{1, t}$ and $Z_{2, t}$ is conducted. The results suggest that for most pairs, they are weakly and insignificantly correlated. For pairs that do show significant correlations, these are less than $50 \%$. For brevity, the correlation results are not presented here but are available on request.

The results from Equation (5) are presented in Tables 4 to 7 . Note that the first row displays the domestic nation with its current account under scrutiny and the source of domestic shocks, while the first column signifies the source of the foreign shock.

The most striking result, which is consistent across all estimations, is the prominence of unexpected domestic shocks in the determination of the current account of all the Asian countries in our sample. Unexpected foreign country innovations are statistically insignificant in all cases. We find that the two developed countries, Japan and the US, show similar results as the Asian countries. These results imply that foreign country shocks are behaving like common shocks in the current account model. 


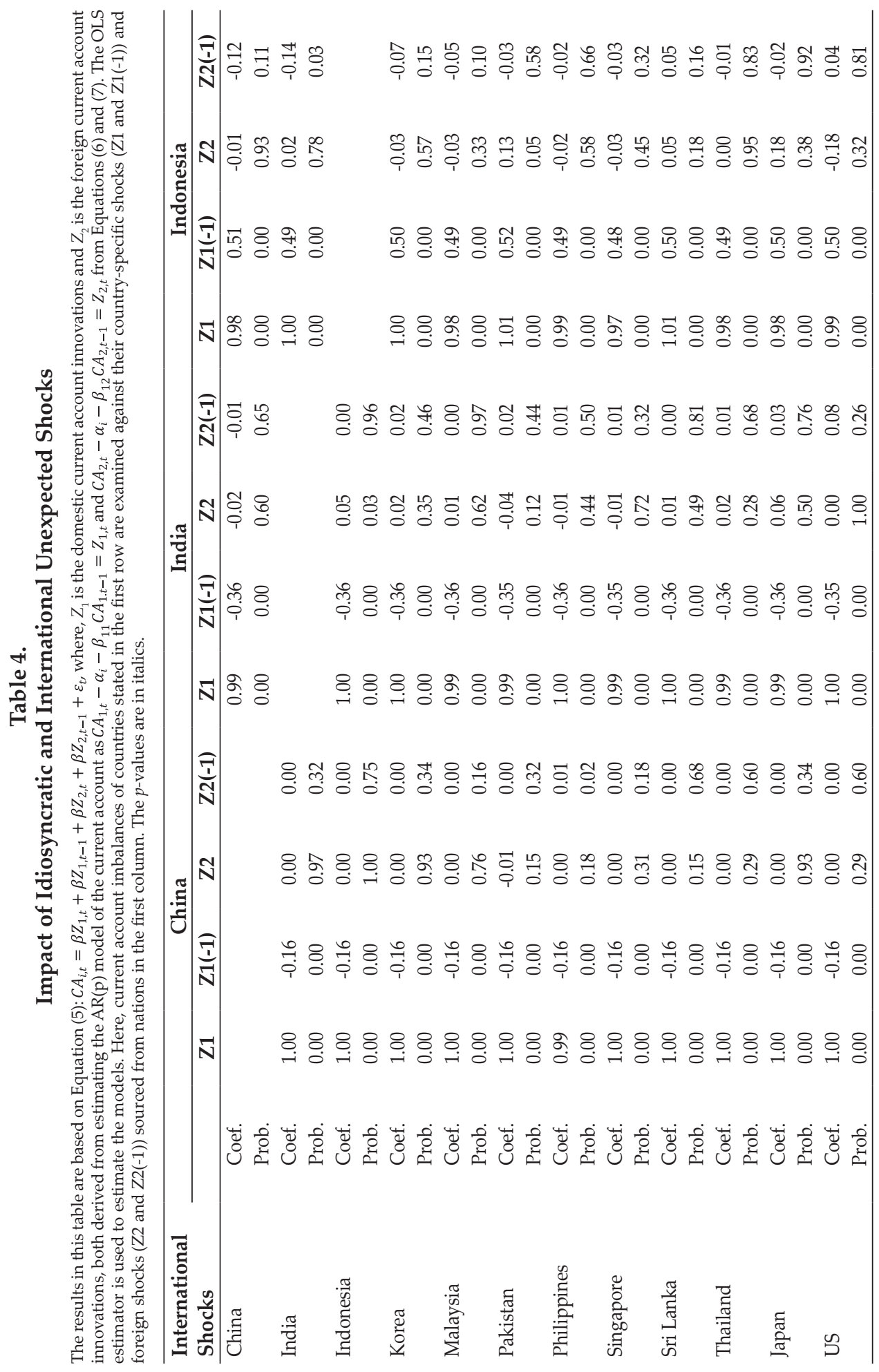




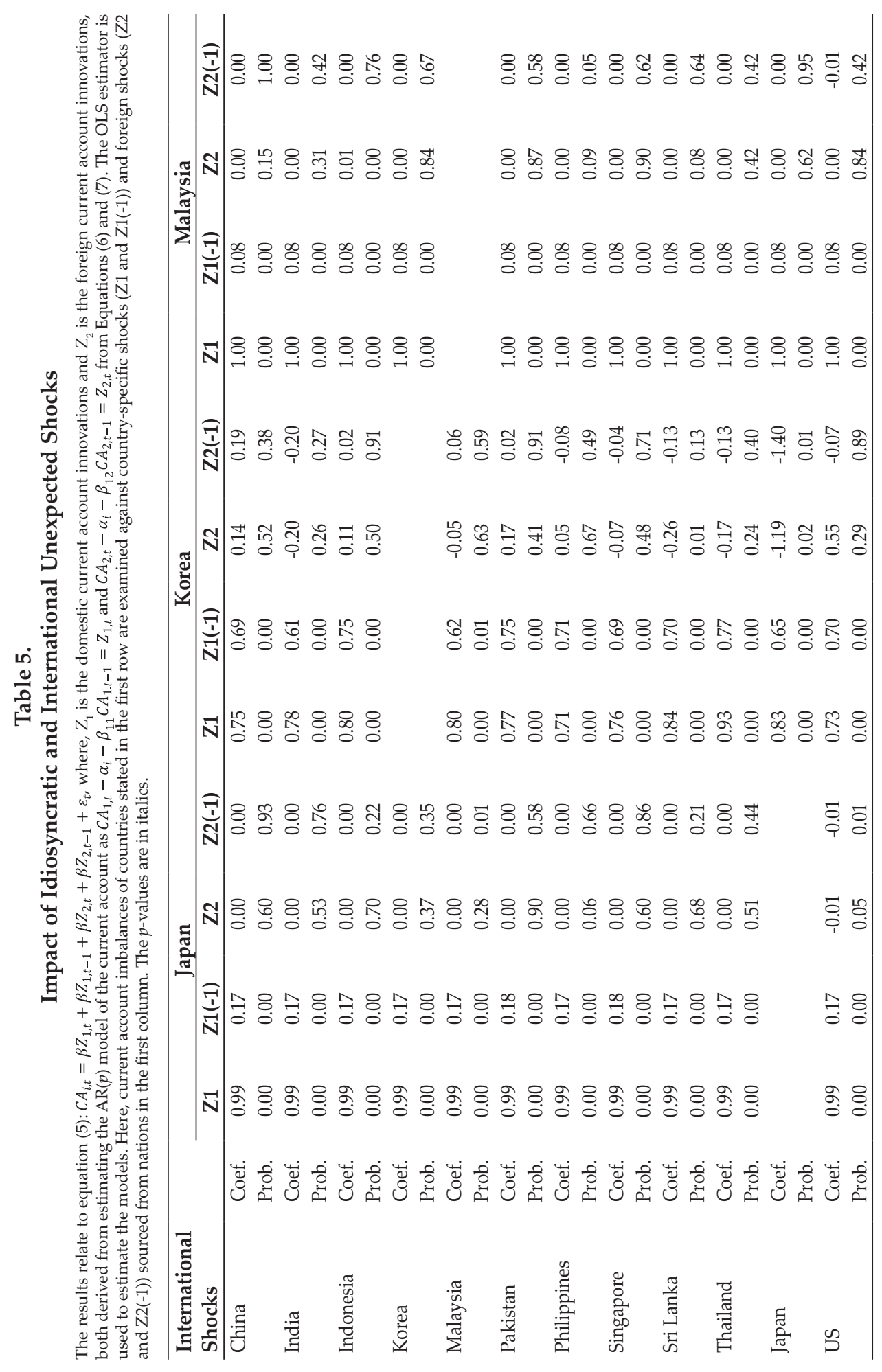




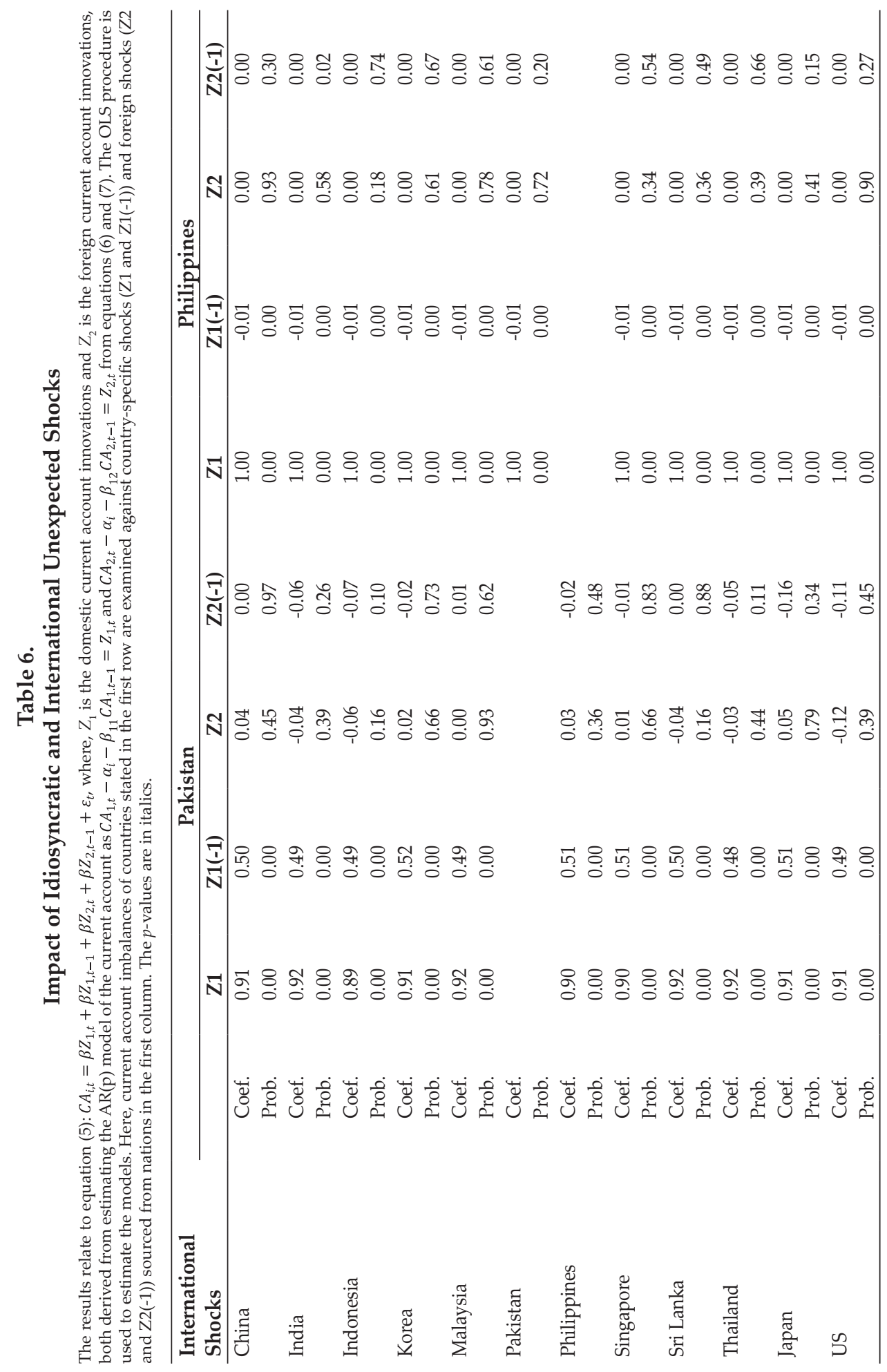




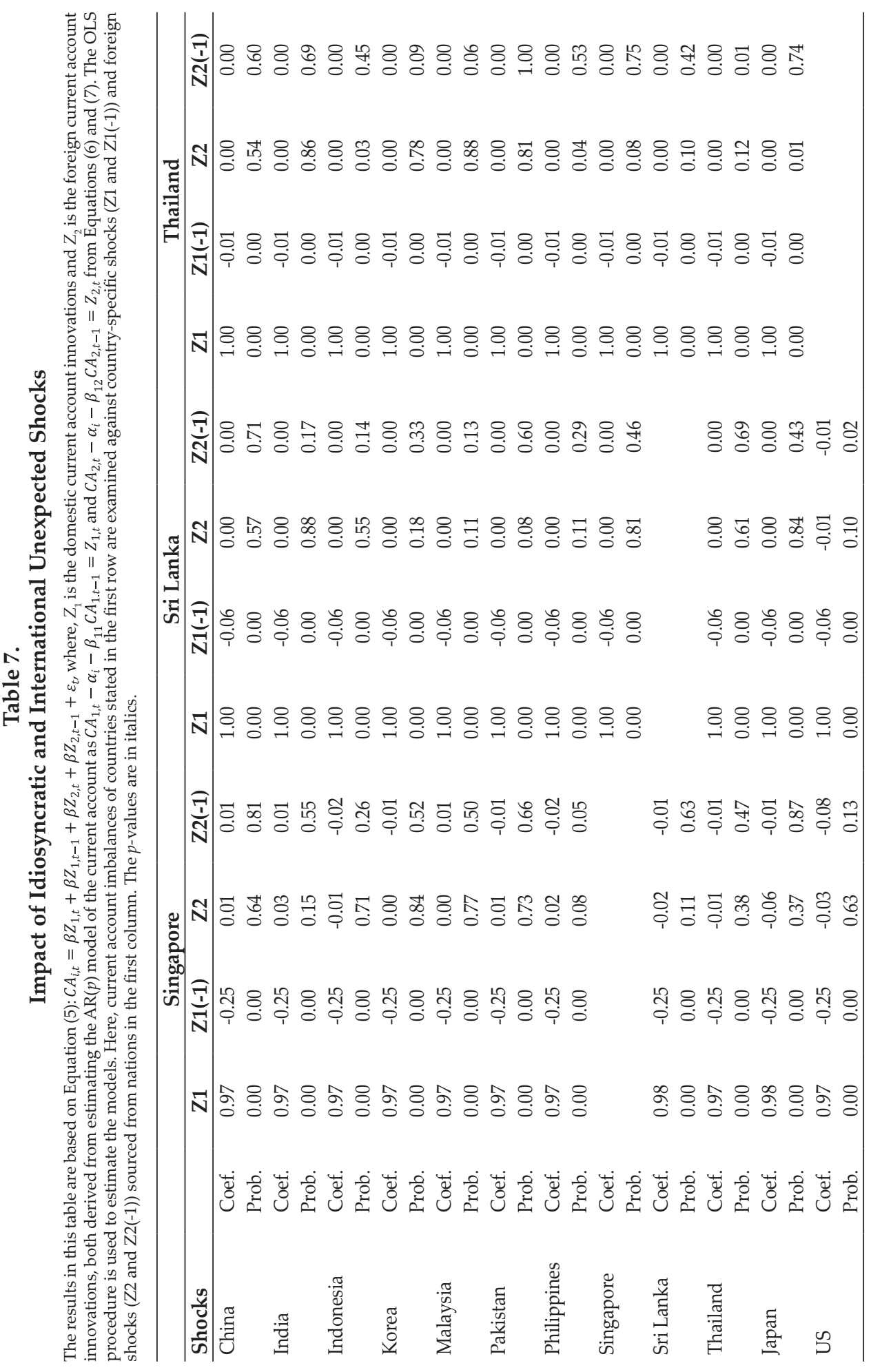


C. The Influence of Unexpected Domestic and Regional Spillovers

The preceding section captures the influence of unanticipated domestic and foreign country shocks on the domestic current account. The focus now turns to foreign spillover effects from a group of foreign countries. Given that a country trades with many nations simultaneously, the group approach is appropriate. In this section, we only consider the Asian region. The equation is re-estimated with domestic $Z_{1}$ and Asian regional shocks $\omega_{t}$ :

$$
C A_{i, t}=\beta_{1} Z_{1, t}+\beta_{2} \omega_{t}+\varepsilon_{i, t}
$$

The domestic current account shocks are taken from the data above, while the regional shocks, $\omega_{t^{\prime}}$ are calculated as a GNI weighted average of 10 Asian countries' current account shocks (this excludes the country whose current account appears on the left-hand side). The regional variable is different for each of the 10 Asian countries.

The results from estimating Equation (8) are presented in Table 8 (Panel 1). The regional-based foreign shocks are found to have insignificant effects on the current account of all Asian countries. The shocks that matter for the current account of these Asian countries are those shocks that originate domestically.

\section{The Influence of Domestic, Regional and US Spillovers}

Together with the domestic and regional spillovers, we also include the US spillovers to account for the global shocks. Equation (2) is, therefore, further extended to include US shocks $\left(Z_{u S, t}\right)$ :

$$
C A_{i, t}=\beta_{1} Z_{1, t}+\beta_{2} \omega_{t}+\beta_{3} Z_{U S, t}+\varepsilon_{t}
$$

All variables are given as above, except $Z_{U S, t^{\prime}}$ which proxies the US current account innovations or unexpected shocks. The results from estimating Equation (9) are presented in Table 8 (see Panel 2). Here, we find that regional- and US- based foreign shocks have insignificant effects on the current account of all these Asian countries, except Japan. Unexpected domestic shocks remain the only significant determinant of the current account of all countries, except Japan. Japan's current account surplus is influenced by unexpected current account shocks in the US, and its own domestic economy. 
Table 8.

\section{Impact of Unanticipated Country-specific and Regional Shocks}

Panel 1 has results from Equation (8): $C A_{t}=\beta_{1} Z_{1, t}+\beta_{2} \omega_{t}+\varepsilon_{t}$. Panel 2 corresponds to estimates from Equation (9): $C A_{t}=\beta_{1} Z_{1, t}+\beta_{2} \omega_{t}+\beta_{3} Z_{U S, t}+\varepsilon_{t}$. Here, $Z_{1^{\prime}} Z_{U S^{\prime}}$ and $\omega_{t}$ are the country-specific, the US, and regional unexpected shocks to the current accounts (CA) of each country. The domestic current account shocks are as described in Table 7 . The regional shocks, $\omega$, are calculated as GNI weighted average of 10 Asian countries' current account shocks (this excludes the country whose current account appears on the left-hand-side). The regional variable is different for each of the 10 Asian countries. Finally, ${ }^{*}, * *$ and ${ }^{* * *}$ denote the level of significance at $10 \%, 5 \%$, and $1 \%$, respectively.

\begin{tabular}{|c|c|c|c|c|c|}
\hline \multirow{2}{*}{ Country } & \multirow[b]{2}{*}{ Variables } & \multicolumn{2}{|c|}{ Panel 1} & \multicolumn{2}{|c|}{ Panel 2} \\
\hline & & Coefficient & $p$-values & Coefficient & $p$-values \\
\hline \multirow[t]{3}{*}{ China } & $Z_{1}$ & $1.000^{* * *}$ & 0.000 & $0.992^{* * *}$ & 0.000 \\
\hline & $\omega_{t}$ & 0.001 & 0.747 & 0.000 & 0.991 \\
\hline & $Z_{u s}$ & - & - & -0.101 & 0.168 \\
\hline \multirow[t]{3}{*}{ India } & $Z_{1}$ & $0.995^{* * *}$ & 0.000 & $0.985^{* * *}$ & 0.000 \\
\hline & $\omega_{t}$ & -0.004 & 0.668 & -0.004 & 0.629 \\
\hline & $Z_{u s}$ & - & - & -0.235 & 0.223 \\
\hline \multirow[t]{3}{*}{ Indonesia } & $Z_{1}$ & $1.017^{* * *}$ & 0.000 & $1.014^{* * *}$ & 0.000 \\
\hline & $\omega_{t}$ & -0.025 & 0.333 & -0.025 & 0.344 \\
\hline & $Z_{u s}^{t}$ & - & - & 0.047 & 0.935 \\
\hline \multirow[t]{3}{*}{ Japan } & $Z_{1}$ & $0.984^{* * *}$ & 0.000 & $0.955^{* * *}$ & 0.000 \\
\hline & $\omega_{t}$ & 0.003 & 0.105 & $0.003^{*}$ & 0.063 \\
\hline & $Z_{u s}$ & - & - & $-0.078^{* *}$ & 0.018 \\
\hline \multirow[t]{3}{*}{ Korea } & $Z_{1}$ & $0.923^{* * *}$ & 0.000 & $0.932^{* * *}$ & 0.000 \\
\hline & $\omega_{t}$ & -0.021 & 0.673 & -0.025 & 0.624 \\
\hline & $Z_{\text {us }}$ & - & - & -0.238 & 0.737 \\
\hline \multirow[t]{3}{*}{ Malaysia } & $\mathrm{Z}_{1}$ & $0.995^{* * *}$ & 0.000 & $0.993^{* * *}$ & 0.000 \\
\hline & $\omega_{t}$ & 0.002 & 0.711 & 0.002 & 0.664 \\
\hline & $Z_{u s}$ & - & - & -0.074 & 0.436 \\
\hline \multirow[t]{3}{*}{ Pakistan } & $Z_{1}$ & $0.919^{* *}$ & 0.014 & $0.913^{* *}$ & 0.017 \\
\hline & $\omega_{t}$ & 0.002 & 0.969 & 0.002 & 0.971 \\
\hline & $Z_{\text {us }}^{t}$ & - & - & -0.179 & 0.852 \\
\hline \multirow[t]{3}{*}{ Philippines } & $\mathrm{Z}_{1}$ & $0.999^{* * *}$ & 0.000 & $0.998^{* * *}$ & 0.000 \\
\hline & $\omega_{t}$ & 0.001 & 0.869 & 0.001 & 0.869 \\
\hline & $Z_{\text {us }}$ & - & - & 0.005 & 0.970 \\
\hline \multirow[t]{3}{*}{ Singapore } & $Z_{1}$ & $0.998^{* * *}$ & 0.000 & $0.995^{* * *}$ & 0.000 \\
\hline & $\omega_{t}$ & 0.002 & 0.876 & 0.003 & 0.826 \\
\hline & $Z_{\text {us }}^{t}$ & - & - & 0.437 & 0.140 \\
\hline \multirow[t]{3}{*}{ Sri Lanka } & $Z_{1}$ & $1.002^{* * *}$ & 0.000 & $1.002^{* * *}$ & 0.000 \\
\hline & $\omega_{t}$ & -0.004 & 0.603 & -0.003 & 0.624 \\
\hline & $Z_{u s}$ & - & - & 0.132 & 0.376 \\
\hline \multirow[t]{3}{*}{ Thailand } & $Z_{1}$ & $1.001^{* * *}$ & 0.000 & $1.001^{* * *}$ & 0.000 \\
\hline & $\omega_{t}$ & -0.001 & 0.630 & 0.000 & 0.720 \\
\hline & $Z_{u s}^{t}$ & - & - & 0.009 & 0.646 \\
\hline
\end{tabular}




\section{E. Expected Foreign Spillovers}

The former models examine the effects of unexpected shocks on the current account assuming perfect foresight. In this sub-section, we examine the effects of anticipated current account shocks - domestic, regional and the US, by modifying Equation (4) to:

$$
C A_{t}=A_{t}, \text { where } A_{t}=E \widetilde{H_{t}}
$$

To derive the anticipated shocks for the domestic economy $\left(A_{d o m, t}\right)$ and the foreign country $\left(A_{\text {for },}\right)$, we use the fitted values of the $\operatorname{AR}(1)$ current account Equations (6) and (7):

$$
\begin{aligned}
& A_{\text {dom }, t}=\alpha_{i}+\beta_{11} C A_{1, t-1} \\
& A_{\text {for }, t}=\alpha_{i}+\beta_{12} C A_{2, t-1}
\end{aligned}
$$

The current account model with the expected components is as below:

$$
\begin{aligned}
& C A_{i, t}=\beta_{1} A_{\text {dom }, t}+\beta_{2} A_{\text {reg }, t}+\varepsilon_{i, t} \\
& C A_{i, t}=\beta_{1} A_{\text {dom }, t}+\beta_{2} A_{\text {reg }, t}+\beta_{3} A_{U S, t}+\varepsilon_{i, t} .
\end{aligned}
$$

Here, the domestic expected shock, $A_{d o m^{\prime}}$ is the fitted values from an $\operatorname{AR}(1)$ current account model (see Equation (6)), while the regional expected shocks, $A_{\text {reg' }}$ is the GNI weighted average of the fitted values of 10 Asian countries, $A_{\text {for }, t}$. Again, the country with the current account under examination is excluded, giving us 11 expected regional shock variables. Also, for completeness, we include the expected US shocks, derived in a manner similar to domestic shocks.

Results from the above two equations are presented in Table 9 in panels 1 and 2, respectively. The current accounts of the Asian countries do not respond to regional- and US- based anticipated foreign shocks. Anticipated domestic shocks, on the other hand, have a significant effect on the current account of a few countries, namely, India, Indonesia, Korea and Pakistan. The current account balances of the other nations - China, Japan, Malaysia, the Philippines, Singapore, Sri Lanka and Thailand - show no significant adjustments to expected domestic shocks. The latter finding is consistent with the standard intertemporal model. Furthermore, the lack of importance of foreign shocks and weak effects of domestic shocks on current account aligns with studies (see Glick and Rogoff and Narayan, 2014) that note the lack of importance of global shocks. 
Table 9:

\section{Impact of Country-specific and Regional Shocks (anticipated)}

Panel 1 of this table presents estimated coefficients from estimating Equation (13): $C A_{t}=\beta_{1} A_{\text {dom,t }}+\beta_{2} A_{\text {reg,t }}+\varepsilon_{\text {it }}$ Panel 2 presents estimated coefficients for equation (14): $C A_{t}=\beta_{1} A_{d o m, t}+\beta_{2} A_{\text {reg,t }}+\beta_{3} A_{U S, t}+\varepsilon$. Here, $A_{d o w,} A_{u S^{\prime}}$ and $A_{t}$ are expected domestic, the US, and regional shocks, respectively. Finally, ${ }^{*}, * *$ and ${ }^{* * *}$ denote the level of significance at $10 \%, 5 \%$, and $1 \%$, respectively.

\begin{tabular}{|c|c|c|c|c|c|}
\hline \multirow{2}{*}{ Country } & & \multicolumn{2}{|c|}{ Panel 1} & \multicolumn{2}{|c|}{ Panel 2} \\
\hline & Variable & Coefficient & $p$-values & Coefficient & $p$-values \\
\hline \multirow[t]{3}{*}{ China } & $A_{\text {dom }}$ & 1.183 & 0.287 & 1.203 & 0.289 \\
\hline & $A_{\text {reg }}$ & 0.016 & 0.291 & 0.016 & 0.300 \\
\hline & $A_{\text {US }}^{\circ}$ & & & -4.448 & 0.865 \\
\hline \multirow[t]{3}{*}{ India } & $A_{\text {dom }}$ & $1.151^{* *}$ & 0.018 & $1.212^{* *}$ & 0.017 \\
\hline & $A_{\text {reg }}$ & -0.030 & 0.138 & -0.030 & 0.139 \\
\hline & $A_{\text {us }}$ & & & -15.783 & 0.601 \\
\hline \multirow[t]{3}{*}{ Indonesia } & $A_{d o m}$ & $1.004^{* * *}$ & 0.000 & $1.016^{* * *}$ & 0.000 \\
\hline & $A_{\text {reg }}$ & 0.007 & 0.753 & 0.008 & 0.751 \\
\hline & $A_{\text {us }}$ & & & -4.550 & 0.909 \\
\hline \multirow[t]{3}{*}{ Japan } & $A_{\text {dom }}$ & 1.014 & 0.168 & $1.437^{*}$ & 0.079 \\
\hline & $A_{\text {reg }}$ & -0.017 & 0.004 & -0.017 & 0.004 \\
\hline & $A_{\text {us }}$ & & & 11.098 & 0.228 \\
\hline \multirow[t]{3}{*}{ Korea } & $A_{d o m}$ & $0.956^{* * *}$ & 0.000 & $0.967^{* * *}$ & 0.000 \\
\hline & $A_{\text {reg }}$ & -0.128 & 0.387 & -0.196 & 0.275 \\
\hline & $A_{\text {US }}^{\circ}$ & & & 29.131 & 0.490 \\
\hline \multirow[t]{3}{*}{ Malaysia } & $A_{\text {dom }}$ & 1.063 & 0.653 & 0.385 & 0.877 \\
\hline & $A_{\text {reg }}$ & -0.003 & 0.946 & 0.004 & 0.941 \\
\hline & $A_{u s}$ & & & -64.044 & 0.367 \\
\hline \multirow[t]{3}{*}{ Pakistan } & $A_{d o m}$ & $0.978^{* * *}$ & 0.000 & $1.007^{* * *}$ & 0.000 \\
\hline & $A_{\text {reg }}$ & 0.002 & 0.914 & 0.002 & 0.916 \\
\hline & $A_{\text {us }}$ & & & -20.306 & 0.543 \\
\hline \multirow[t]{3}{*}{ Philippines } & $A_{\text {dom }}$ & 1.009 & 0.353 & -0.519 & 0.647 \\
\hline & $A_{r e g}$ & -0.015 & 0.672 & -0.011 & 0.742 \\
\hline & $A_{u s}$ & & & -147.069 & 0.010 \\
\hline \multirow[t]{3}{*}{ Singapore } & $A_{d o m}$ & $0.990^{*}$ & 0.092 & $1.260^{* *}$ & 0.050 \\
\hline & $A_{\text {reg }}$ & -0.005 & 0.893 & -0.005 & 0.908 \\
\hline & $A_{u s}^{\circ}$ & & & 68.328 & 0.268 \\
\hline \multirow[t]{3}{*}{ Sri Lanka } & $A_{d o m}$ & 1.010 & 0.362 & 1.402 & 0.269 \\
\hline & $A_{\text {reg }}$ & -0.046 & 0.237 & -0.047 & 0.231 \\
\hline & $A_{u s}$ & & & 41.741 & 0.504 \\
\hline \multirow[t]{3}{*}{ Thailand } & $A_{\text {dom }}$ & 0.713 & 0.928 & 2.544 & 0.787 \\
\hline & $A_{r e g}$ & -0.037 & 0.265 & -0.037 & 0.269 \\
\hline & $A_{u S}$ & & & 20.736 & 0.713 \\
\hline
\end{tabular}

\section{CONCLUDING REMARKS}

This study examined the importance of domestic and foreign shocks for the determinations of selected Asian countries' current account. The study was conducted over the period 1978-2012, a turbulent period when the Asian nations were mostly invested heavily in liberalizing trade and financial activities and 
engaging in activities that promoted export-led growth and significant flow of capital.

Empirical investigations into the impact of domestic and foreign shocks on the current account revealed that foreign spillovers, sourced from a foreign country, a region, and the US, had an insignificant influence on the current account of almost all Asian countries. Both domestic and foreign shocks were derived as unexpected (current account innovations) or expected (fitted values of the current account) shocks.

In all, the study shows the irrelevance of expected and unexpected foreign shocks and anticipated domestic shocks in the determination of the current account of selected Asian nations. Unanticipated domestic shocks were found to influence the current account. This study contributes to the literature by providing an overall picture on the importance of domestic and foreign shocks on the current account. There is scope to extend the study in several directions. First, the foreign and domestic shocks used in the study were transitory in nature, hence this study depicted the case where the current account is affected by only transitory shocks. Some versions of the intertemporal model of the current account have implications for anticipated and unanticipated permanent shocks that affect the current account as well. This is an aspect of research we devote to future work. Second, foreign shocks were sourced from the current accounts of foreign countries and these shocks were only confined to Asian countries, a region, and the US. This opens up the possibility of exploring other forms of the foreign shock. Third, the paper only explored outcomes of the standard intertemporal model of the current account. There is scope to explore other extensions of this modern theory in the quest to improve our understanding of the current account.

\section{REFERENCES}

Ahmed, S., and Park, J. H. (1994). Sources of Macroeconomic Fluctuations in Small Open Economies. Journal of Macroeconomics, 16, 1-36.

Bergin, P. R., and Sheffrin, S. M. (2000). Interest Rates, Exchange Rates and Resent Value Models of the Current Account. Economic Journal, 110, 535-558.

Campbell, J. Y. (1987). Does Saving Anticipate Declining Labor Income? An Alternative Test of the Permanent Income Hypothesis, Econometrica, 55, 12491274.

Cashin, P., and McDermott C. J. (2002). Terms of Trade Shocks and the Current Account: Evidence from Five Industrial Countries. Open Economies Review 13, 219-235.

Corden, W. M. (2009). China's Exchange Rate Policy, Its Current Account Surplus and the Global Imbalances, The Economic Journal, 119, 430-441.

Chinn, M. D., and Ito, H. (2007a). Current Account Balances, Financial Development, and Institutions: Assaying the "World Saving Glut", Journal of International Money and Finance, 26, 546-569.

Chinn, M. D., and Ito, H. (2007b). East Asia and Global Imbalances: Saving, Investment and Financial Development, NBER Working paper, 13364.

Chinn, M. D., and Prasad, E. S. (2003). Medium-term Determinants of Current Accounts in Industrial and Developing Countries: An Empirical Exploration. Journal of International Economics, 59, 47-76. 
Dibooglu, S. (1997). Accounting for US Current Account Deficits: An Empirical Investigation. Applied Economics. 29, 787-93.

Edwards, S. (1989). Temporary Terms of Trade Disturbances, the Real Exchange Rate and the Current Account. Economica 56, 343-357.

Engler, P., Fidora, M., and Thiman, C. (2009). External Imbalances and the US Current Account. How Supply-Side Changes Affect an Exchange Rate Adjustment, Review of International Economics, 17, 927-941.

Ghosh, A. R. (1995). International Capital Mobility amongst the Major Industrialised Countries: Too Little or Too Much? Economic Journal, 105, 107-128.

Glick, R., and Rogoff, K. (1995). Global versus Country-Specific Productivity Shocks and the Current Account. Journal of Monetary Economics, 35, 159-192.

Greenwood, J. 1983. Expectations, the Exchange Rate and the Current Account. Journal of Monetary Economics, 12, 543-569.

Gregory, A. W., and Head, A. C. (1999). Common and Country-Specific Fluctuations in Productivity, Investment and the Current Account. Journal of Monetary Economics, 44, 423-451.

Gruber, J. W., and Kamin, S. B. (2007). Explaining the Global Pattern of Current Account Imbalances, Journal of International Money and Finance, 26, 500-522.

Gruber, J. W. and Kamin, S. (2009). Do Differences in Financial Development Explain The Global Pattern of Current Account Imbalances? Review of International Economics, 17, 667-688.

Hoffman, M. (2013). What Drives China's Current Account? Journal of International Money and Finance, 32, 856-883.

Hossain, F. (1999). Transitory and Permanent Disturbances and the Current Account: An Empirical Analysis in the Intertemporal Framework. Applied Economics, 31, 965-974.

Hubbard, G. (2006). The US Current Account Deficit and Public Policy, Journal of Policy Modeling, 28, 665-71.

Iscan, T. B. (2000) The Terms of Trade, Productivity Growth and the Current Account, Journal of Monetary Economics, 45, 587-612.

Kaufmann, S., Scharler, J., and Winckler, G. (2002). The Austrian Current Account Deficit: Driven by Twin Deficits or by Intertemporal Expenditure Allocation? Empirical Economics 27. 529-542.

Kent, C., and Cashin, P. (2003). The Response of the Current Account to Terms of Trade Shocks: Persistence Matters. IMF Working Paper, WP/03/143.

Kim, B-H., Min, H-G., Hwang, Y-S., and McDonald, J. A. (2009). Are Asian Countries Current Accounts Sustainable? Deficits, Even When Associated with High Investment, Are Not Costless, Journal of Policy Modelling, 31, 163-179.

Longin, F., and Solnik, B. (1995). Is the Correlation in International Equity Returns Constant: 1960-1990?, Journal of international Money and Finance, 10, 231-251.

Mendoza, E. G., Vincenzo, Q., and Ros-Rull, J.-V. (2007) Financial Integration, Financial Deepness and Global Imbalances, NBER Working Paper 12909.

Narayan, S. (2009). A Survey on Dynamics of Current Account Imbalances. The Indian Economic Journal, 57, 3-26.

Narayan, S., (2014). Integration of the Current Account Imbalances in the OECD, Economic Modelling, 38, 288-295. 
Narayan, S., Sriananthakumar, S., and Islam, S. (2014). Stock Market Integration of Emerging Asian Economies: Patterns and Causes. Economic Modelling, 39, 19-31

Narayan, S. and Rehman, M. (2017). Diversification Opportunities between Emerging and Frontier Asian (EFA) and Developed Stock Markets, Finance Research Letters, 23, 223-232.

Narayan, S and Rehman, M. (2018). Portfolio Diversification Opportunities within Emerging and Frontier Stock Markets: Evidence From Ten Asian Countries, Bulletin of Monetary Economics and Banking, 21, 1-21.

Narayan, S and Rehman, M. (2019). International Portfolio Strategies and Opportunities: The Case of the US, Japan and Asia, Finance Research Letters, In Press. https://doi.org/10.1016/j.frl.2019.101358.

Narayan, S., Bui, M-H. (2019). Does Corruption in Exporter and Importer Country Influence International Trade? Emerging Markets Finance and Trade.

DOI: 10.1080/1540496X.2019.1679116

Narayan, S. (2019). The Influence of Domestic and Foreign Shocks on Portfolio Diversification Gains and the Associated Risks. Journal of Risk Financial Management, 12, 160.

Narayan, S., and Nguyen, T.T. (2019). Are Exports More Responsive to Clean or Dirty Energy? The Case of Vietnam's Exports to 54 Countries. Energies, 12, 1558.

Nason, J. M. and Rogers, J. H. (2002). Investment and the Current Account in the Short Run and The Long Run, Journal of Money, Credit, and Banking, 34, 967-986.

Obstfeld, M., and Rogoff, K. (1996). Foundations of International Macroeconomics. MIT Press, Cambridge.

Ogawa, E., and Iwatsubo, K. (2009). External Adjustments and Coordinated Exchange Rate Policy in Asia, Journal of Asian Economics, 20, 225-239.

Otto, G. (1992). Testing a Present-Value Model of the Current Account: Evidence from US and Canadian Times Series, Journal of International Money and Finance, $11,414-430$.

Rogoff, K. (2007). Global Imbalances and Exchange Rate Adjustment, Journal of Policy Modeling, 29, September-October 705-709.

Sheffrin, S. M and Woo, T. W. (1990). Present Value of An Intertemporal Model of the Current Account. Journal of International Economics, 29, 237-253.

Wälti, S. (2011). Stock Market Synchronization and Monetary Integration, Journal of International Money and Finance, 30, 96-110.

Yang, D. T. (2012). Aggregate Savings and External Imbalances in China, Journal of Economic Perspective, 26, 125-146. 